\title{
Lumiestrone is photochemically derived from estrone and may be released to the environment without detection
}

\author{
Vance L. Trudeau ${ }^{1}$ *, Belinda Heyne ${ }^{2,3}$, Jules M. Blais ${ }^{1}$, Fabio Temussi ${ }^{2,4}$, Susanna K. Atkinson ${ }^{1}$, \\ Farzad Pakdel ${ }^{5}$, Jason T. Popesku ${ }^{1}$, Vicki L. Marlatt ${ }^{1}$, Juan C. Scaiano ${ }^{2}$, Lucio Previtera ${ }^{4}$ and \\ David R. S. Lean'
}

\author{
1 Department of Biology, Centre for Advanced Research in Environmental Genomics, University of Ottawa, Ottawa, ON, Canada \\ 2 Department of Chemistry, University of Ottawa, Ottawa, ON, Canada \\ ${ }^{3}$ Department of Chemistry, University of Calgary, Calgary, AB, Canada \\ ${ }^{4}$ Dipartimento Chimica Organica e Biochimica, Universita Federico II Napoli, Napoli, Italia \\ ${ }^{5}$ UMR CNRS 6026, IFR 140, Université de Rennes 1, Rennes, France
}

\section{Edited by:}

Gustavo M. Somoza, Instituto de Investigaciones

Biotecnologicas-Instituto Tecnologico de Chascomus, Argentina

\section{Reviewed by:}

T. John Wu, Uniformed Services University of the Health Sciences, USA

Juan Ignacio Fernandino, Instituto Tecnológico de Chascomus (CONICET-UNSAM), Argentina

\section{*Correspondence:}

Vance L. Trudeau, Department of Biology, Centre for Advanced

Research in Environmental Genomics, University of Ottawa, Gendron Hall, Room 160, 30 Marie Curie, Ottawa, ON, Canada e-mail:trudeauv@uottawa.ca
Endocrine disrupting chemicals are adversely affecting the reproductive health and metabolic status of aquatic vertebrates. Estrone is often the dominant natural estrogen in urban sewage, yet little is known about its environmental fate and biological effects. Increased use of UV-B radiation for effluent treatments, and exposure of effluents to sunlight in holding ponds led us to examine the effects of environmentally relevant levels of UV-B radiation on the photodegradation potential of estrone. Surprisingly, UV-B-mediated degradation leads to the photoproduction of lumiestrone, a little known 13 $\alpha$-epimer form of estrone. We show for the first time that lumiestrone possesses novel biological activity. In vivo treatment with estrone stimulated estrogen receptor (ER) \& mRNA production in the male goldfish liver, whereas lumiestrone was without effect, suggesting a total loss of estrogenicity. In contrast, results from in vitro ER-dependent reporter gene assays indicate that lumiestrone showed relatively higher estrogenic potency with the zebrafish ER $\beta 2$ than zfER $\alpha$, suggesting that it may act through an ER $\beta$-selectivity. Lumiestrone also activated human ERs. Microarray analysis of male goldfish liver following in vivo treatments showed that lumiestrone respectively up- and down-regulated 20 and 69 mRNAs, which was indicative of metabolic upsets and endocrine activities. As a photodegradation product from a common estrogen of both human and farm animal origin, lumiestrone is present in sewage effluent, is produced from estrone upon exposure to natural sunlight and should be considered as a new environmental contaminant.

Keywords: environmental estrogens, estrone, lumiestrone, fish, endocrine disruption, liver, sewage effluents, photochemistry

\section{INTRODUCTION}

There is strong evidence linking exposure to estrogenic endocrine disrupting chemicals (EDCs) with the feminization of male wildlife, the decline of some species, and potential effects on human development and fertility (Guillette et al., 2007; Kidd et al., 2007; Hotckiss et al., 2008; Ottinger et al., 2008; Desforges et al., 2010; Mouritsen et al., 2010; Harris et al., 2011). Estrogenic chemicals also have effects in mollusks (Hotckiss et al., 2008) and even plants (Fox et al., 2004). Some EDCs have been linked to metabolic upsets and obesity (Decherf and Demeneix, 2011). Nevertheless, great debate continues on whether environmental levels of these and other EDCs are sufficiently biologically active to be of concern. However, the key examples of feminization of alligators and fish, and the decline and elimination of some species following contamination of lakes clearly indicates that environmental estrogens are affecting wildlife on a large scale (Guillette et al., 2007; Kidd et al., 2007; Hotckiss et al., 2008; Desforges et al., 2010). Perhaps most convincing is the ecosystems level study by Kidd et al. (2007). They reported on experimental contamination of a large
(34 ha) freshwater lake in the Experimental Lakes Area of Canada with the contraceptive ethinyl-estradiol (EE2). This direct addition of EE2 led to the feminization of male fathead minnows as indicated by the production of the egg yolk protein vitellogenin, intratesticular ovarian tissues, and near extinction of the species from the lake (Kidd et al., 2007). In wild roach in UK rivers, feminization resulting from pollution is a major problem that is linked to reduced fertility (Harris et al., 2011). Most studies on estrogenic EDCs in human wastewater effluents focus either on EE2 or the natural steroid estradiol $17-\beta$ (E2). This is surprising given that estrone (E1) is often the most abundant estrogen in the wastewater of some sewage treatment facilities (Williams et al., 2003; Johnson et al., 2005; Servos et al., 2005; Kumar et al., 2011), is found in farm sewage (Hutchins et al., 2005), soil (Ying and Kookana, 2005), and ocean sediments (Braga et al., 2004). Moreover, surprisingly little is known about the biological activity of E1 in aquatic vertebrates.

The investigation of steroidal estrogen behavior under ultraviolet (UV) radiation is important because when estrogens are released to the environment, they are exposed to solar radiation 
(UVA; $\lambda=320-400 \mathrm{~nm}$, and UV-B; $\lambda=280-320 \mathrm{~nm}$ ). Estrone, $17 \beta$-estradiol (E2), and $17 \alpha$-ethinyl-estradiol (EE2) are candidates for UV photodegradation because they show maximum absorbance peaks in the UV spectrum (Coleman et al., 2004). Not reaching the earth's surface is the highly destructive UVC band ( $\lambda=240-280 \mathrm{~nm}$ ) that is filtered by the ozone layer. However, UVC lamps are used widely in STP treatment as an effective disinfection tool (Das, 2001). Combinations of UV and other remediation methods for the removal and degradation of E1 and other estrogens have also been reported (Coleman et al., 2004; Lin and Reinhard, 2005). Yet, the environmental fate of E1 and many other EDCs is still controversial. We (Atkinson et al., 2011) and others (Coleman et al., 2004; Liu and Liu, 2004) have reported on UV-mediated degradation of E1, and in some cases there appears to be some reduction in estrogenicity. On the other hand, some studies report no effect of UV on estrogen degradation (Cicek et al., 2007). In the course of our previous investigations (Atkinson et al., 2011) we found that UV-mediated degradation of E1 led to the formation of an unknown product that we identify and characterize here. We found that E1 can be rapidly photochemically converted to lumiestrone, a little known steroid that we also determined to be biologically active, rapidly produced upon natural sunlight exposure and present in urban sewage effluent.

\section{MATERIALS AND METHODS DETECTION OF ESTROGENS}

One liter water grab samples of sewage effluents were collected in amber, air-tight bottles that were pre-rinsed with dichloromethane (ACS grade, Fisher Scientific) and baked overnight at $200^{\circ} \mathrm{C}$. Water samples were stored in the dark at $4^{\circ} \mathrm{C}$ for up to $48 \mathrm{~h}$. Immediately after sampling an isotope dilution was done by adding a C-13 labeled internal standards (Cambridge Isotope Laboratories, Andover, MA, USA) of E1, E2, and EE2 in acetonitrile. Extraction and analysis for steroidal estrogens followed previous strategies (Lee and Peart, 1998; Kuch and Ballschmiter, 2001) as validated in our laboratory (Atkinson et al., 2011). The samples were prefiltered through a $1.2-\mu \mathrm{m}$ glass fiber filter and subsequently loaded onto a pre-treated $1 \mathrm{~g}$ ENVI-18 solid phase extraction (SPE) cartridge at a flow rate of $10 \mathrm{~mL} / \mathrm{min}$. The SPE was eluted with $5 \mathrm{~mL}$ acetone followed by $5 \mathrm{~mL}$ methanol. The extract was evaporated to dryness with nitrogen gas, and re-dissolved in $2 \mathrm{~mL}$ of high-pressure liquid chromatography (HPLC) water. A 10\% pentafluorobenzoyl chloride derivative in toluene and $2 \mathrm{M}$ potassium hydroxide was added to the sample and vortexed. After phase separation, the organic phase was extracted twice with $2.5 \mathrm{~mL}$ hexane and evaporated to $0.5 \mathrm{~mL}$. The sample was subsequently passed through a sodium sulfate column, eluted with $7 \mathrm{~mL}$ of hexane, and evaporated to $200 \mu \mathrm{l}$ for analysis on an Agilent 6890 gas chromatograph with a 5973 Mass Selective Detector in negative chemical ionization mode. One microliter was injected onto a Zebron ZB-5MS $30 \mathrm{~m}, 250 \mu \mathrm{m}, 0.25 \mu \mathrm{m}$ column with a flow rate of $1 \mathrm{~mL} / \mathrm{min}$ of helium gas. The oven ramping commenced with $80^{\circ} \mathrm{C}$ held for $1 \mathrm{~min}$, increasing at $24^{\circ} \mathrm{C} / \mathrm{min}$ to $200^{\circ} \mathrm{C}$ and held for half a minute, $73^{\circ} \mathrm{C} / \mathrm{min}$ until $245^{\circ} \mathrm{C}$ and held for $5 \mathrm{~min}$, and then $1^{\circ} \mathrm{C} / \mathrm{min}$ to $260^{\circ} \mathrm{C}$. The mass spectrometer used methane as the reaction gas at a flow rate of $40 \mathrm{~mL} / \mathrm{min}$ with the quad at $100^{\circ} \mathrm{C}$ and the source at $200^{\circ} \mathrm{C}$. The ${ }^{12} \mathrm{C}$ ions monitored were E1/lumiestrone 464, E2 466, and EE2 490 and the ${ }^{13} \mathrm{C}$ ions were 466,468 , and 492 , respectively. Both E1 and lumiestrone produced identical ion fragmentation patterns, and were quantified using identical protocols. Chromatographic data were collected and analyzed using Agilent MSD Chemstation Data Analysis Software.

The method detection limits (MDLs) were calculated using the protocol of the United States Environmental Protection Agency (1993). The MDLs were obtained by injection of seven extracts from seven water samples (prepared from E1 and EE2 standards of 5 and $1 \mathrm{ng} \mathrm{L}^{-1}$, respectively, in $1 \mathrm{~L}$ double distilled water), where the SD for the mean concentration was multiplied by the onetailed t statistic at a $95 \%$ confidence level. In addition, the linear responses of steroidal estrogens were determined from sample extracts of $0,12.5,25,37.5 \mathrm{ng} \mathrm{L}^{-1}$ of E1 standards and from sample extracts of $0,1,2,3$, and $4 \mathrm{ng} \mathrm{L}^{-1}$ of EE2 standards. Blank samples of double distilled water and blank samples of hydromatrix were spiked with the ${ }^{13} \mathrm{C}$ standards and taken through the extraction process. The MDL for E1 and EE2 in water were 1.8 and $0.3 \mathrm{ng} \mathrm{L}^{-1}$ respectively. No commercial standards are available for lumiestrone, but its ion fragmentation pattern and MDL are identical to E1.

\section{PURIFICATION AND CHARACTERIZATION OF LUMIESTRONE}

Mid-day UV-B intensity along the Ottawa River (Ontario), typical of a partly cloudy day in summer was measured to be $\sim 110$ $140 \mathrm{~mW} \mathrm{~cm}^{-2}$ using the GOLDILUX radiometer/photometer GRP-1 (Model 70237) with an UV-BR probe GBP-1 (Model 0238). This measurement was used to design environmentally relevant UV exposures in controlled laboratory conditions. In another experiment, a solution of E1 $(0.1 \mathrm{mM})$ dissolved in acetonitrile was irradiated with UVC in a photoreactor (model LZC-4V, Luzchem). Under various experimental conditions, the disappearance of E1 and the formation of its main photoproduct (lumiestrone) were followed by gas chromatography (GC); the solution was injected directly after irradiation on the column (Agilent HP-5MS, $0.25 \mathrm{~mm} \times 30 \mathrm{~m} \times 0.25 \mu \mathrm{m}$ ) of the GC/MS chromatogram (Agilent Technologies). The injector temperature was set at $250^{\circ} \mathrm{C}$. The temperature program began at $50^{\circ} \mathrm{C}$ (for $10 \mathrm{~min}$ ) and was increased up to $280^{\circ} \mathrm{C}$ (for $10 \mathrm{~min}$ ) at a rate of $10^{\circ} \mathrm{C} / \mathrm{min}$. The temperature of the MS detector (Agilent, model 5973) was set at $150^{\circ} \mathrm{C}$. In these conditions, by using 7 UVC lamps in the photoreactor, the almost complete conversion of $\mathrm{E} 1$ into lumiestrone was observed after $5 \mathrm{~min}$ irradiation. Lumiestrone was then purified by preparative high performance liquid chromatography. The purification was carried out on a preparative system from Shimadzu (model: LC-8A) equipped with a UV-detector (model: SPD-10A), the column employed was a preparative reverse-phase C-18 column (Supelco, discovery HS C-18, $250 \mathrm{~mm} \times 21.2 \mathrm{~mm} \times 5 \mu \mathrm{m}$ ). Lumiestrone was obtained as a pure product after $17 \mathrm{~min}$ using an isocratic elution with $70 \%$ acetonitrile and $30 \%$ water and a flow of $10 \mathrm{~mL} / \mathrm{min}$. Lumiestrone was then characterized by nuclear magnetic resonance spectroscopy (NMR; Fielding et al., 2001). NMR spectra were recorded at $400 \mathrm{MHz}$ for $\left[{ }^{1} \mathrm{H}\right]$ and $100 \mathrm{MHz}$ for $\left[{ }^{13} \mathrm{C}\right]$ on a Bruker Avance 400 spectrometer. The carbon multiplicity was assessed by distortionless enhancement by polarization transfer (DEPT). The proton couplings were evidenced by ${ }^{1} \mathrm{H}-{ }^{1} \mathrm{H}$ COSY experiments. The heteronuclear chemical shift correlations 
were determined by HMQC and HMBC pulse sequences. The sample was prepared in methyl sulfoxide- $\mathrm{d}_{6}(99 \%)$ purchased from Aldrich.

\section{IN VITRO REPORTER GENE ASSAYS}

The zebrafish (zf) zfER $\alpha$, zfER $\beta 1$, and zfER $\beta 2$ expression vectors, correspond to Topo-pcDNA3 expression vector (Invitrogen, San Diego, CA, USA), containing the coding regions of each receptor CDNA, as previously described (Menuet et al., 2002; Métivier et al., 2002). The cyp19b-Luc reporter gene consists of $500 \mathrm{bp}$ of the proximal promoter region of zebrafish cyp $19 b$ gene, containing an estrogen response element (ERE), coupled to the firefly luciferase reporter gene (Le Page et al., 2006, 2008). The ERE-tkLuc reporter gene consists of a consensus ERE with a minimal thymidine kinase promoter driving firefly luciferase activity. The cytomegalovirus- $\beta$-galactosidase (CMV- $\beta$ gal) was used as control internal plasmid. These vectors were described previously (Menuet et al., 2002; Métivier et al., 2002). The U251-MG (ER-negative glial cell line) and MCF-7 (ER-positive breast cancer cell line) cells were maintained at $37^{\circ} \mathrm{C}$ under a $5 \% \mathrm{CO}_{2}$ atmosphere in Dulbecco's modified Eagle medium (DMEM; Sigma, St. Louis, MO, USA) supplemented with $10 \%$ fetal calf serum (FCS; Life Technologies, Carlsbad, CA, USA), $100 \mathrm{U} / \mathrm{mL}$ penicillin, $100 \mathrm{mg} / \mathrm{mL}$ streptomycin, and $25 \mathrm{mg} / \mathrm{mL}$ amphotericin (Sigma-Aldrich, St. Louis, MO, USA). U251-MG cells were plated in 24-well plates at a density of $0.2 \times 10^{5}$ cells $/ \mathrm{mL}$. U251-MG were transfected with $25 \mathrm{ng}$ of zfER expression vector, $150 \mathrm{ng}$ of luciferase reporter construct and $25 \mathrm{ng}$ of CMV- $\beta$ gal control plasmid. MCF-7 were plated in 24-well plates at a density of $0.5 \times 10^{5} \mathrm{cells} / \mathrm{mL}$ and transfected with $50 \mathrm{ng}$ of ERE-TK-Luc and $25 \mathrm{ng}$ of CMV- $\beta$ gal per well. Transfection assays were performed with FuGENE 6 transfection reagent (Roche, Basel, Switzerland). After one night, medium was replaced with fresh DMEM-F12 containing 2\% charcoal/dextran FCS with estrogenic test chemical or vehicle. The luciferase activities were assayed $48 \mathrm{~h}$ later using the luciferase assay system (Promega, Madison, WI, USA). We used $\beta$-galactosidase activity to normalize for transfection efficiency in all experiments. Each experiment was performed at least in triplicate.

\section{IN VIVO TREATMENTS AND GENE EXPRESSION ANALYSIS}

All in vivo protocols were approved by the University of Ottawa Animal Care and Veterinary Services and were in accordance with the Canadian Council on Animal Care. Sexually regressed male goldfish were injected intraperitoneally with E2 $(0.5 \mu \mathrm{g} / \mathrm{g})$, E1 $(0.5 \mu \mathrm{g} / \mathrm{g})$, and lumiestrone $(0.5 \mu \mathrm{g} / \mathrm{g})$ or control vehicle (in charcoal-stripped peanut oil; $5 \mu \mathrm{L} / \mathrm{g}$ ). Animals were anesthetized in MS222, and livers were harvested $24 \mathrm{~h}$ after injection, frozen on dry ice, and stored at $-80^{\circ} \mathrm{C}$ until RNA extraction, cDNA synthesis and real-time multiplex PCR analysis for the three fish ERs or vitellogenin- 1 by a SYBR-green-based simplex assay as validated in our laboratory (Marlatt et al., 2008) using the $\mathrm{Mx} 4000^{\oplus}$ Multiplex Quantitative PCR System (Stratagene, La Jolla, CA, USA). Analysis of the $\sim 10 \mathrm{~K}$ carp-goldfish microarray data including statistical analysis followed our established and well-validated strategies (Gracey et al., 2004; Martyniuk et al., 2006; Williams et al., 2008). Pooled control liver cDNA was hybridized against four independent samples from lumiestrone-treated males. Hybridizations were performed using the protocol supplied by Genisphere. Microarrays were scanned at full speed $10 \mu \mathrm{m}$ resolution using the ScanArray 5000 XL system (Packard Biosciences/PerkinElmer) using both red and blue lasers. Images were obtained with ScanArray Express software using automatic calibration sensitivity varying PMT gain (PMT starting at $65 \%$ for $\mathrm{Cy} 5$ and $70 \%$ for $\mathrm{Cy} 3$ ) with fixed laser power at $80 \%$ and the target intensity set for $90 \%$. Microarray images were analyzed using QuantArray (Packard Biosciences/Perkin Elmer) and raw signal intensity values were obtained for duplicate spots of genes. We used Alien Spot Report Genes 1-10 (Stratagene, La Jolla, CA, USA) to normalize microarray data and the Significance Analysis of Microarray method (Tusher et al., 2001; SAM) for microarray analysis. Candidate genes identified as being differentially regulated $(q$-value $<5)$ were further analyzed using the GOSSIP package in Blast2GO (Conesa et al., 2005) for gene ontology categorizations. The microarray data are accessible via the Gene Ontology Omnibus at NCBI (accession no. GSE12252).

\section{RESULTS AND DISCUSSION}

When E1 was placed in either distilled water or river water and exposed to an environmentally relevant level of UV-B $\left(135 \mathrm{~mW} \mathrm{~cm}^{-2}\right)$, a photodegradation product of the same molecular weight as E1 was obtained. This shows that the process is direct and not a photosensitized reaction. The appearance of this unknown photoproduct confirms our previous observations (Atkinson et al., 2011). This photoproduct was isolated by preparative HPLC and characterized by NMR as the $13 \alpha$-epimer form of

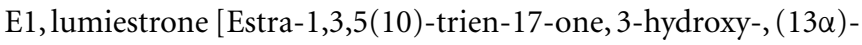
(9CI)]. To determine the process of formation of lumiestrone, a series of fundamental photochemical experiments were realized in organic solvent. As observed, brief irradiation of E1 with UV$\mathrm{B}$ under aerobic conditions in acetonitrile leads to the almost complete conversion of E1 into lumiestrone (Figure 1). Longer irradiations induce the complete disappearance of $\mathrm{E} 1$, and eventually lumiestrone, indicating that the photoproduct is more robust than the parent compound (Figure 1).

Electron paramagnetic resonance spectroscopy using gaseous nitric oxide $\left(\mathrm{NO}^{\bullet}\right)$ as the spin trap coupled to irradiation of an E1 solution yields a nitroxide radical signal $\left(a_{\mathrm{N}}=7.3 \mathrm{G}\right.$; Figure A1 in Appendix) very close to the one reported for cyclopentanone (Maruthamuthu and Scaiano, 1978). This proves that $13 \alpha$-epimerization of E1 is via the Norrish type I photocleavage of a cyclic ketone as depicted in Figure 2.

Nanosecond laser flash photolysis experiments were also undertaken. Lumiestrone was produced and no traces of bi-radical formation were observed in the nanosecond time scale, indicating a rapid conversion $(<20 \mathrm{~ns})$ of E1 to lumiestrone. UVA was also used in order to photodamage E1 but no phototransformations were observed since E1 does not absorb in this region. Significantly, UV-B irradiation of E1 in water (with $<1 \%$ ethanol) also leads to the formation of a single product, lumiestrone (Figure A2 in Appendix). Untreated sewage water obtained from the Mercato san Severino sewage treatment plant (Salerno, Italy) was filtered to remove grit. Estrone was dissolved in this sewage water and irradiated by natural sunlight in July in Napoli, Italy. This is environmentally relevant because effluents can be exposed to 

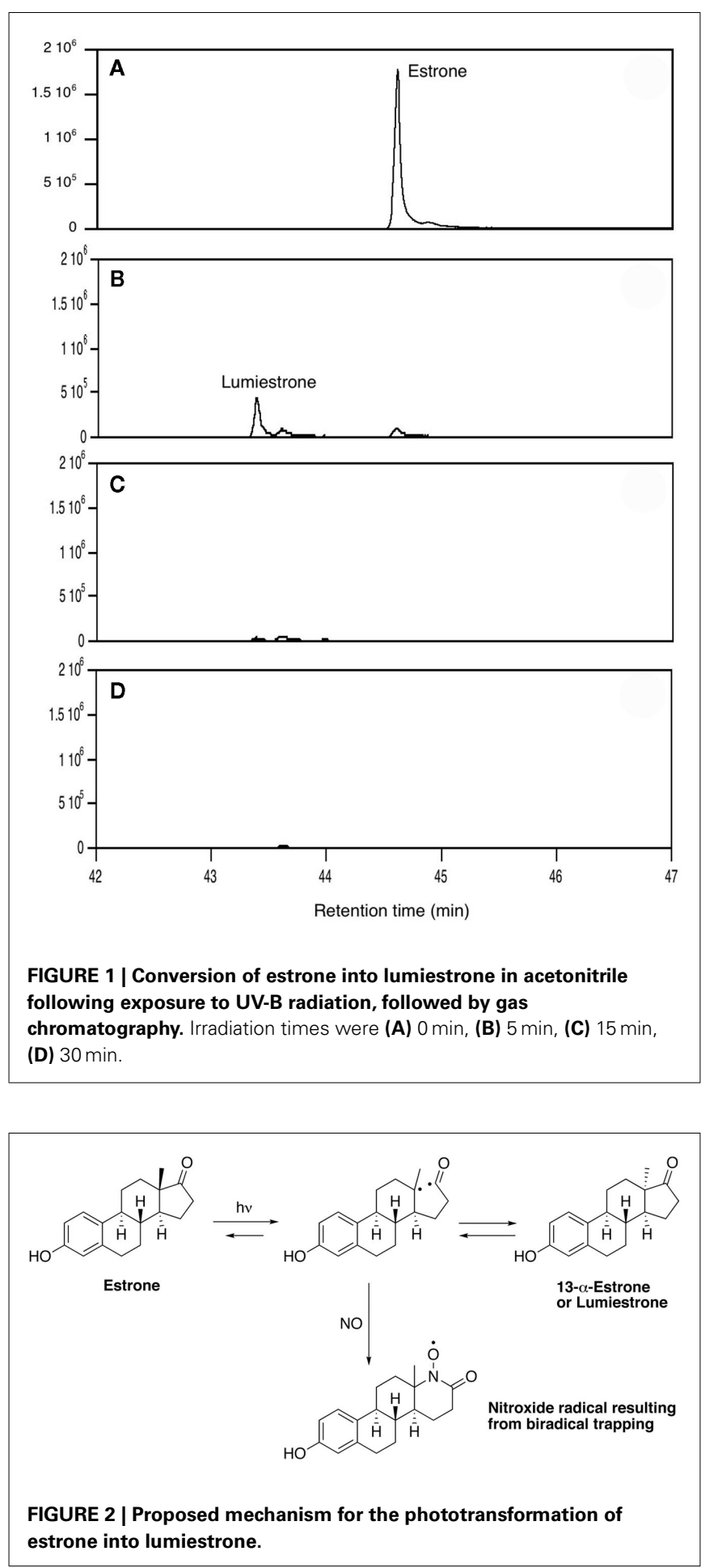

sunlight in holding ponds or as they are released to the receiving environment. Degradation is slower than under laboratory conditions, probably related to reduced penetration of UV-B in a dark sewage sample relative to clear water, but lumiestrone is still the only photodegradation product (Figure A3 in Appendix). Lumiestrone could be detected by HPLC within $60 \mathrm{~min}$. Additionally, sewage water spiked with E1 (10 $\mu \mathrm{M})$ was exposed to UV-B irradiation and lumiestrone could be detected with HPLC within 1 min (Figure A4 in Appendix). After 10 min E1 was degraded but lumiestrone persisted.

Is lumiestrone biologically active? A common screening strategy for assessing estrogenicity of environmental chemicals involves treatment of male fish and quantification of estrogen-dependent gene expression in the liver. The promoter of estrogen receptor alpha $(E R \alpha)$ genes of teleost fish contain a functional, sensitive, and characterized ERE. Thus, the auto-regulation response of $E R \alpha$ serves as a sensitive physiologically relevant biomarker for estrogenicity (Martyniuk et al., 2006, 2007; Marlatt et al., 2008). Multiplex real-time RT-PCR determination of all three known nuclear ERs in goldfish revealed that E1 and E2 stimulated 80- to 90-fold increases in hepatic ER $\alpha(p<0.01$; Figure A5 in Appendix), but not the other ER receptor subtypes. In marked contrast, lumiestrone did not affect expression of any of these genes $(p>0.05)$, suggesting that it is not estrogenic. Therefore we pursued two other approaches to test if $13 \alpha$-epimerization of E1 indeed leads to complete loss of biological activity. All three compounds were screened through established highly sensitive reporter gene assays in vitro. Transfection of ER-negative U251MG human glial cells with zebrafish $E R \alpha, E R \beta 1, E R \beta 2$, and the cyp19ß-Luc reporter revealed that E1 and E2 activated all three receptors. At high dose (at final concentration 100-fold more than E2 or E1), lumiestrone activated both zfER $\alpha$ and zfER $\beta 2$, but not zfER $\beta 1$. Lumiestrone showed relatively higher estrogenic potency with $\mathrm{zfER} \beta 2$ than $\mathrm{zfER} \alpha$, suggesting that it may act through an ER $\beta$-selectivity (Figures 3A-C). This modest estrogenicity was confirmed in ER $\alpha$ and ER $\beta$-positive human breast cancer MCF-7 cells transfected with the ERE-tk-Luc reporter. In both cell-based assays, even at high concentrations $(1000 \mathrm{nM})$, lumiestrone did not show full estrogenic activity but $20-70 \%$ of the maximal activity induced by E2 (Figure 3D). This level of estrogenicity for lumiestrone is similar to or greater than numerous other chemicals with known endocrine disrupting activities (Andersen et al., 1999).

These in vitro results indicate that lumiestrone activates both fish and human ER. As of yet, there are no known direct or indirect gene targets of the ER $\beta 2$ in fish, therefore, we adopted a microarray strategy to determine if indeed lumiestrone possess biological activity in vivo. Microarray screening of livers from control and lumiestrone-injected male goldfish revealed that a single injection of the major E1 photoproduct is biologically active. Statistical analysis indicated that 20 and 69 mRNAs were upor down-regulated, respectively. Of these 89 mRNAs, 22 were identified using Blast2GO (Table A1 in Appendix; $q<5$ and fold change cutoff $>1.4$ ), while the remaining 67 were expressed sequence tags that were not identifiable and were excluded from further analysis. As determined by standard gene ontology classifications, eight biological processes were affected by lumiestrone (Table A1 in Appendix). These categorizations were statistically significant and include three to six identified genes (Table A1 in Appendix) related to signal transduction [6], cellular protein metabolic processes [5], transport [4], macromolecule biosynthetic processes [3], cellular biosynthetic processes [3], cellular component assembly [3], organelle organization and biogenesis [3], and DNA-dependent regulation of transcription [3]. Based on the genes we could assign functions, the effects of lumiestrone 


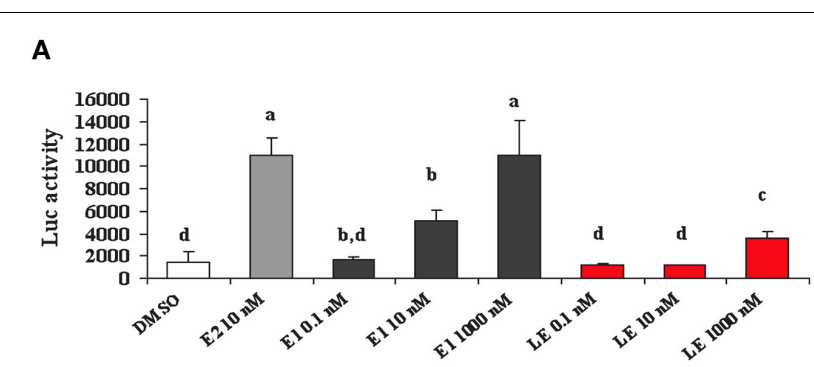

B

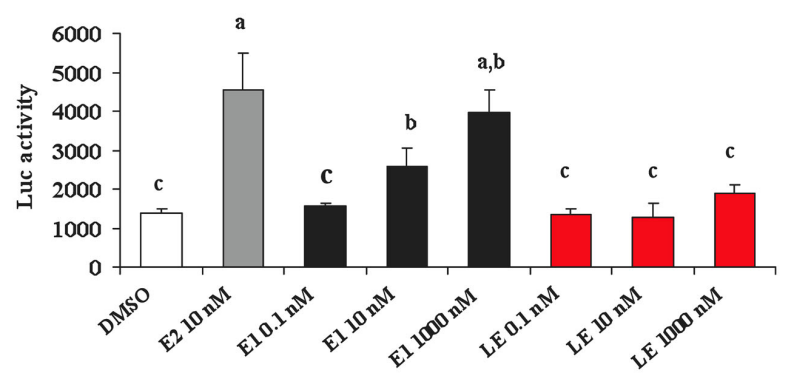

C

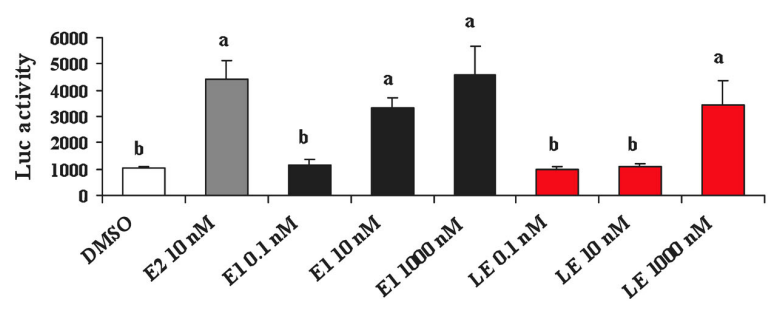

D

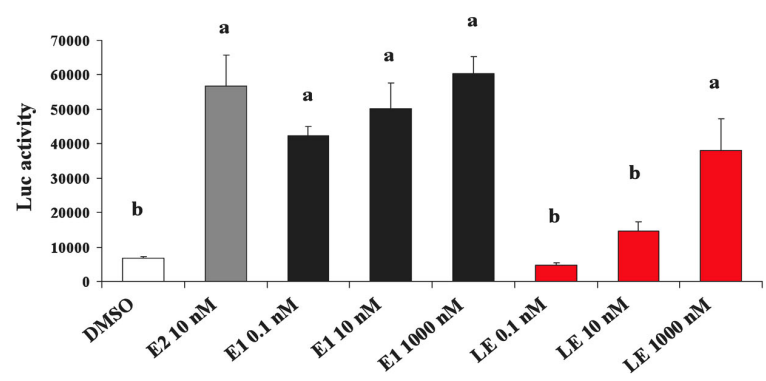

FIGURE 3 | Screening transcriptional activities of estradiol (E2), estrone (E1) and lumiestrone (LE) using estrogen receptor-dependent reporter gene assays in vitro. ER-negative $U 251-M G$ glial cells were transfected with zebrafish $E R \alpha$ ( (A)), $E R \beta 1$ (B), and $E R \beta 2$ (C) and exposed to estrogens or the dimethyl sulfoxide (DMSO) control. In (D) ER $\alpha$ and ER $\beta$-positive human breast cancer MCF-7 cells were used. Data are presented as mean + SEM of luciferase activity relative to $\beta$-gal $(n=3)$. Data were tested for normality and homoscedasticity, and were transformed when appropriate prior to analysis by one-way ANOVA (treatment; $p<0.001$ ) followed by Tukey's post hoc test (S-Plus, v8.0). a,b,c,d Means labeled with different superscripts are significantly different $(p<0.05)$.

appear to be that of metabolic upset, perhaps linked to changes in the various biosynthetic processes, and/or detoxification. For example, increased expression of glutathione $S$-transferase rho may be expected to contribute to increased detoxification, while a decrease in cytochrome oxidase subunit 1 may be indicative of reduced oxidative metabolism. At least three genes affected by lumiestrone are indicative of endocrine disruption. Lumiestrone decreased expression of a high-mobility box protein, which is a coactivator that regulates ER binding to the ERE (Das et al., 2004). Both somatostatin-1b and the type 2 somatostatin receptor (SSTR2) were upregulated by lumiestrone, indicating an effect on a growth regulatory system. It is noteworthy that the human SSTR2 has functional EREs (Kimura et al., 2008). Somatostatins and their receptors in the liver control fibrogenesis in mammals (Reynaert et al., 2005) and insulin-like growth factor production in fish (Very et al., 2008). Importantly, only 25\% (22/89) of the differentially expressed genes could be identified, so other biological pathways and effects of lumiestrone could be expected but will require de-orphanization of these other expressed sequence tags. Overall, both the in vitro reporter gene assays and the microarray data indicate that lumiestrone is a biologically active estrogenic derivative of E1.

To the best of our knowledge the hepatic transcriptional profile for E1 has not been determined in any fish. Direct comparison of the microarray data obtained for lumiestrone to E1 is therefore not possible at this time. Nevertheless, the hepatic transcriptional responses to lumiestrone are clearly different from previously published data for both steroidal and non-steroidal estrogenic EDCs in two related Cyprinidae species, the common carp (Moens et al., 2007) and zebrafish (Martyniuk et al., 2007). The only similarities we noted were the effects of these estrogenic chemicals on glutamine synthetase (GS) and apolipoprotein, both of which are also linked to metabolic effects. Glutamine synthetase- 1 is upregulated in carp liver after various estrogenic exposures (Moens et al., 2007). Here we observed that lumiestrone upregulated glutamine synthase-2. Glutamine synthetase catalyzes the ATP-dependent formation of glutamine from ammonia and glutamate, and is important for detoxification of ammonia (Murray et al., 2003). Moreover, GS may be an early marker for hepatocellular carcinoma in humans (Long et al., 2010). In our previous work, the contraceptive EE2 decreased apolipoprotein A1 mRNA in male zebrafish liver (Martyniuk et al., 2007), while here we observed a decrease in hepatic apolipoprotein Eb mRNA after lumiestrone treatment in male goldfish. Apolipoproteins are important for lipid transport, lipoprotein metabolic process and are implication in numerous conditions, for example, abnormalities of blood lipids and in cardiovascular disease.

Analysis of samples from a wastewater treatment plant (Ottawa, Canada) with secondary treatment indicates that lumiestrone is a candidate environmental contaminant of concern. We detected $\mathrm{E} 1$ in $100 \%$, E2 in 55\%, and both EE2 and lumiestrone in $10 \%$ of samples of raw sewage $(n=10)$ and final effluent $(n=10)$. Mean ( $\pm \mathrm{SD}$; with range) concentrations in sewage for E1, E2, EE2, and lumiestrone were respectively, $103( \pm 21 ; 11-370), 18$ ( $\pm 21 ; 0-67), 0.14( \pm 0.4 ; 0-1.3)$, and 0.05 ( $\pm 0.14 ; 0-0.46) \mathrm{ng} / \mathrm{L}$. Mean $( \pm S D$; with range) concentrations in final effluent for E1, $\mathrm{E} 2, \mathrm{EE} 2$, and lumiestrone were respectively, 49 ( $\pm 115 ; 35-103), 8$ $( \pm 10 ; 0-27), 0.06( \pm 0.18 ; 0-0.6)$, and $0.03( \pm 0.1 ; 0-0.34) \mathrm{ng} / \mathrm{L}$. We have not determined at which stage in sewage handling and 
treatment that lumiestrone would be produced. However, the frequency of detection of lumiestrone in the low $\mathrm{ng} / \mathrm{L}$ range is similar to EE2 in our study and also comparable to dozens pharmaceuticals of concern already recognized as wastewater contaminants (Kolpin et al., 2002; Metcalfe et al., 2003). Critically missing are more detailed analyses of the steps in wastewater processing when E1 could be converted to lumiestrone, more completely degraded or sequestered by sediments.

Lumiestrone is photochemically produced from E1 and therefore is not directly of biological origin. It is plausible that lumiestrone can be formed at any stage where sewage would be exposed to sunlight. This suggestion is based on the short time and low level of UV energy required to generate lumiestrone under experimental conditions in several aqueous media, and in sewage effluent exposed to natural sunlight. This could happen during transport through sewage systems to the water treatment plant, during aeration procedures, or in settling ponds prior to and after the release to the aquatic receiving environment. Another possible process that may produce lumiestrone in wastewater is during UV treatment of sewage, which is beginning to be commonplace in some countries (Das, 2001; Yoon et al., 2004; Hébert et al., 2008; Bilotta and Daniel, 2010; Friedler and Gilboa, 2010).

In conclusion, we demonstrate UV-B-mediated production of lumiestrone, a novel photoproduct derived from an environmentally relevant estrogenic steroid. While sewage treatment has improved considerably, there are still no widespread methods for removing environmental estrogens that pose a risk to the health of vertebrates (Guillette et al., 2007; Kidd et al., 2007; Hotckiss et al., 2008; Ottinger et al., 2008; Desforges et al., 2010; Mouritsen et al., 2010; Decherf and Demeneix, 2011; Harris et al., 2011). Most treatment facilities currently in operation are not designed to remove natural or synthetic estrogens or the multitude of biologically active pharmaceuticals or chemicals found in personal health

\section{REFERENCES}

Al-Ansari, A. M., Saleem, A., Kimpe, L. E., Sherry, J. P., McMaster, M. E., Trudeau, V. L., and Blais, J. M. (2010). Bioaccumulation of the pharmaceutical 17alphaethinylestradiol in shorthead redhorse suckers (Moxostoma macrolepidotum) from the St. Clair River, Canada. Environ. Pollut. 158, 2566-2571.

Andersen, H. R., Andersson, A. M., Arnold, S. F., Autrup, H., Barfoed, M., Beresford, N. A., Bjerregaard, P., Christiansen, L. B., Gissel, B., Hummel, R., Jørgensen, E. B., Korsgaard, B., Le Guevel, R., Leffers, H., McLachlan, J., Møller, A., Nielsen, J. B., Olea, N., OlesKarasko, A., Pakdel, F., Pedersen, K. L., Perez, P., Skakkeboek, N. E., Sonnenschein, C., Soto, A. M., Sumpter, J. P., Thorpe, S. M., and Grandjean, P. (1999). Comparison of short-term estrogenicity tests for identification of hormonedisrupting chemicals. Environ.
Health Perspect. 107(Suppl. 1), 89-108.

Atkinson, S. K., Marlatt, V. L., Kimpe, L. E., Lean, D. R., Trudeau, V. L., and Blais, J. M. (2011). Environmental factors affecting ultraviolet photodegradation rates and estrogenicity of estrone and ethinylestradiol in natural waters. Arch. Environ. Contam. Toxicol. 60, 1-7.

Bilotta, P., and Daniel, L. A. (2010). Advanced process of microbiological control of wastewater in combined system of disinfection with UV radiation. Water Sci. Technol. 61, 2469-2475.

Braga, O., Smythe, G. A., Schäfer, A. I., and Feitz, A. J. (2004). Steroid estrogens in ocean sediments. Water Res. 38, 3233-3240.

Cicek, N., Londry, K., Oleszkiewicz, J. A., Wong, D., and Lee, Y. (2007). Removal of selected natural and synthetic estrogenic compounds in a Canadian full-scale municipal wastewater treatment plant. Water Environ. Res. 79, 795-800.

care products. That one pollutant, E1, itself abundant and biologically active, can be transformed into an epimer with significantly different biological activity suggests that other phototransformations involving at least some of the hundreds of other EDCs found in sewage and released into aquatic ecosystems over the world may be possible. This will not only be an added problem for developed nations where there is the possibility for secondary and tertiary treatments including artificial UV treatments. In rural villages or megacities in developing nations, it may be worse where sewage from farms or urban and suburban regions is released without any treatment. Given that sewage lagoons in swine, poultry, dairy, and beef cattle farms all contain very high amounts of E1, and numerous other estrogens in $\mathrm{ng} / \mathrm{L}$ to $\mu \mathrm{g} / \mathrm{L}$ range (Hutchins et al., 2005), production of lumiestrone and other novel chemicals is likely. Estrone can also be found in ocean sediments (Braga et al., 2004) and persistence of estrogens from sewage biosolid applications to soil indicate that E1 is also in terrestrial environments (Ying and Kookana, 2005). We showed that natural levels of solar radiation can catalyze the formation of the new endocrine-active pollutant lumiestrone. As we have done for EE2 (Al-Ansari et al., 2010), it will be important in future studies to determine uptake and bioconcentration potentials to fully understand the impact of lumiestrone on aquatic vertebrates.

\section{ACKNOWLEDGMENTS}

We thank D. Roberston (Ottawa) and G. Giacometi (Salerno) for sewage effluent samples, L. Kimpe for estrogen analysis, E. Gerrie for PCR analysis, K. Crump for microarray hybridization, $\mathrm{H}$. Xiong for microarray data normalization, A. Boudot for cell cultures, and L. Yao for figures. Funding by NSERC-Canada (Vance L. Trudeau, Belinda Heyne, Jules M. Blais, David R. S. Lean) and the University of Calgary (Belinda Heyne) is acknowledged with appreciation.

Coleman, H. M., Routledge, E. J., Sumpter, J. P., Eggins, B. R., and Byrne, J. A. (2004). Rapid loss of estrogenicity of steroid estrogens by UVA photolysis and photocatalysis over an immobilized titanium dioxide catalyst. Water Res. 38, 3233-3240.

Conesa, A., Götz, S., García-Gómez, J. M., Terol, J., Talón, M., and Robles, M. (2005). Blast2GO: a universal tool for annotation, visualization and analysis in functional genomics research. Bioinformatics 21, 3674-3676.

Das, D., Peterson, R. C., and Scovell, W. M. (2004). High mobility group B proteins facilitate strong estrogen receptor binding to classical and half-site estrogen response elements and relax binding selectivity. Mol. Endocrinol. 18, 2616-2232.

Das, T. K. (2001). Ultraviolet disinfection application to a wastewater treatment plant. Clean Prod. Process. 3, 69-80.
Decherf, S., and Demeneix, B. A. (2011). The obesogen hypothesis: a shift of focus from the periphery to the hypothalamus. J. Toxicol. Environ. Health B Crit. Rev. 14, 423-448.

Desforges, J.-P. W, Peachey, B. D. L., Sanderson, P. M., White, P. A., and Blais, J. M. (2010). Plasma vitellogenin in male teleost fish from 43 rivers worldwide is correlated with upstream human population size. Environ. Pollut. 158, 3279-3284.

Fielding, L., Diepeveen, Y., Fletcher, D., and Hamilton, N. (2001). Unnaturally configured 13-epi steroids: full $1 \mathrm{H}$ and $13 \mathrm{C}$ assignments and ring C - D conformations from $1 \mathrm{H}$, $1 \mathrm{H}$ vicinal couplings. Magn. Reson. Chem. 39, 323-328.

Fox, J. E., Starcevic, M., Joners, P. E., Burow, M. E., and McLachlan, J. A. (2004). Phytoestrogen signaling and symbiotic gene activation are disrupted by endocrine-disrupting chemicals. Environ. Health Perspect. $112,672-677$. 
Friedler, E., and Gilboa, Y. (2010). Performance of UV disinfection and the microbial quality of greywater effluent along a reuse system for toilet flushing. Sci. Total Environ. 408, 2109-2117.

Gracey, A. Y., Fraser, E. J., Li, W., Fang, Y., Taylor, R. R., Rogers, J., Brass, A., and Cossins, A. R. (2004). Coping with cold: an integrative, multitissue analysis of the transcriptome of a poikilothermic vertebrate. Proc. Natl. Acad. Sci. U.S.A. 101, 16970-16975.

Guillette, L.J. Jr., Edwards, T. M., and Moore, B. C. (2007). Alligators, contaminants and steroid hormones. Environ. Sci. 14, 331-347.

Harris, C. A., Hamilton, P. B., Runnalls, T. J., Vinciotti, V., Henshaw, A., Hodgson, D., Coe, T. S., Jobling, S., Tyler, C. R., and Sumpter, J. P. (2011). The consequences of feminization in breeding groups of wild fish. Environ. Health Perspect. 119, 306-311.

Hébert, N., Gagné, F., Cejka, P., Bouchard, B., Hausler, R., Cyr, D. G., Blaise, C., and Fournier, M. (2008). Effects of ozone, ultraviolet and peracetic acid disinfection of a primary-treated municipal effluent on the immune system of rainbow trout (Oncorhynchus mykiss). Comp. Biochem. Physiol. C Toxicol. Pharmacol. 148, 122-127.

Hotckiss, A. K., Rider, C. V., Blystone, C. R., Wilson, V. S., Hartig, P. C., Ankley, G. T., Foster, P. M., Gray, C. L., and Gray, L. E. (2008). Fifteen years after "wingspread"- environmental endocrine disrupters and human and wildlife health: where we are today and where we need to go. Toxicol. Sci. 105, 235-259.

Hutchins, S. R., White, M. V., Hudson, F. M., and Fine, D. D. (2005). Analysis of lagoon samples from different concentrated animal feeding operations for estrogens and estrogen conjugates. Chemosphere 61, 827-833.

Johnson, A. C., Aerni, H. R., Gerritsen, A., Gibert, M., Giger,. W, Hylland, K., Jürgens, M., Nakari, T., Pickering, A., Suter, M. J., Svenson, A., and Wettstein, F. E. (2005). Comparing steroid estrogen, and nonylphenol content across a range of European sewage plants with different treatment and management practices. Water Res. 39, 47-58.

Kidd, K. A., Blanchfield, P. J., Mills, K. H., Palace, V. P., Evans, R. E., Lazorchak, J. M., and Flick, R. W. (2007). Collapse of a fish population after exposure to a synthetic estrogen. Proc. Natl. Acad. Sci. U.S.A. 104, 8897-8901.

Kimura, N., Takamatsu, N., Yaoita, Y., Osamura, R. Y., and Kimura,
N. (2008). Identification of transcriptional regulatory elements in the human somatostatin receptor sst2 promoter and regions including estrogen response element halfsite for estrogen activation. J. Mol. Endocrinol. 40, 75-91.

Kolpin, D. W., Furlong, E. T., Meyer, M. T., Thurman, E. M., Zaugg, S. D., Barber, L. B., and Buxton, H. T. (2002). Pharmaceuticals, hormones, and other organic wastewater contaminants in U.S. streams, 1999-2000: a national reconnaissance. Environ. Sci. Technol. 36, 1202-1211.

Kuch, H. M., and Ballschmiter, K. (2001). Determination of endocrine-disrupting phenolic compounds and estrogens in surface and drinking water by HRGC(NIC)-MS in the pictogram per litre range. Environ. Sci. Technol. 35, 3201-3206.

Kumar, V., Nakada, N., Yamashita, N., Johnson, A. C., and Tanaka, H. (2011). How seasonality affects the flow of estrogens and their conjugates in one of Japan's most populous catchments. Environ. Pollut. 159, 2906-2912.

Le Page, Y., Menuet, A., Kah, O., and Pakdel, F. (2008). Characterization of a cis-acting element involved in cell-specific expression of the zebrafish brain aromatase gene. $\mathrm{Mol}$. Reprod. Dev. 75, 1549-1557.

Le Page, Y., Scholze, M., Kah, O., and Pakdel, F. (2006). Assessment of xenoestrogens using three distinct estrogen receptors and zebrafish brain aromatase gene in a highly responsive glial cell system. Environ. Health Perspect. 114, 752-758.

Lee, H. B., and Peart, T. E. (1998). Determination of $17 \beta$-estradiol and its metabolites in sewage effluent by solid-phase extraction and gas chromatography/mass spectrometry. J. AOAC Int. 81, 1209-1216.

Lin, A. Y., and Reinhard, M. (2005). Photodegradation of common environmental pharmaceuticals and estrogens in river water. Environ. Toxicol. Chem. 24, 1303-1309. [Erratum in: Environ. Toxicol. Chem. 2005, 24, 3000].

Liu, B., and Liu, X. (2004). Direct photolysis of estrogens in aqueous solutions. Sci. Total Environ. 320, 269-274.

Long, J., Lang, Z. W., Wang, H. G., Wang, T. L., Wang, B. E., and Liu, S. Q. (2010). Glutamine synthetase as an early marker for hepatocellular carcinoma based on proteomic analysis of resected small hepatocellular carcinomas. Hepatobiliary Pancreat. Dis. Int. 9, 296-305.

Marlatt, V. L., Martyniuk, C. J., Zhang, D., Xiong, H., Watt, J., Xia, X., Moon,
T., and Trudeau, V. L. (2008). Tissuespecific auto-regulation of estrogen receptor subtypes and gene expression profiling of $17 \beta$-estradiol action in the neuroendocrine axis of male goldfish (Carassius auratus). J. Mol. Endocrinol. 283, 38-48.

Martyniuk, C. J., Gerrie, E. R., Popesku, J. T., Ekker, M., and Trudeau, V. L. (2007). Microarray analysis in the zebrafish liver (Danio rerio) and telencephalon after exposure to low concentration of $17 \alpha$ ethinyl-estradiol. Aquat. Toxicol. 84, 38-49.

Martyniuk, C. J., Xiong, H., Crump, K., Chiu, S., Sardana, R., Nadler, A., Gerrie, E. R., Xia, X., and Trudeau, V. L. (2006). Gene expression profiling in the neuroendocrine brain of male goldfish (Carassius auratus) exposed to 17- $\alpha$ ethinylestradiol. Physiol. Genomics 27, 328-336.

Maruthamuthu, O., and Scaiano, J. C. (1978). Biradical double trapping by nitric oxide. An electron spin resonance study. J. Phys. Chem. 82, 1588-1591.

Menuet, A., Pellegrini, E., Anglade, I., Blaise, O., Laudet, V., Kah, O., and Pakdel, F. (2002). Molecular characterization of three estrogen receptor forms in zebrafish: binding characteristics, transactivation properties and tissue distributions. Biol. Reprod. 66, 1881-1892.

Metcalfe, C. D., Koenig, B. G., Bennie, D. T., Servos, M., Ternes, T. A., and Hirsch, R. (2003). Occurrence of neutral and acidic drugs in the effluents of Canadian sewage treatment plants. Environ. Toxicol. Chem. 22, 2872-2880.

Métivier, R., Gay, F., Hübner, M. R. Flouriot, G., Salbert, G., Gannon, F., Kah, O., and Pakdel, F. (2002). Formation of an hER $\alpha$-COUPTFI complex enhances hER $\alpha$, AF-1 through Ser118 phosphorylation by MAPK. EMBO J. 21, 3443-3453

Moens, L. N., van der Ven, K., Van Remortel, P., Del-Favero, J., and De Coen, W. M. (2007). Gene expression analysis of estrogenic compounds in the liver of common carp (Cyprinus carpio) using a custom cDNA microarray. J. Biochem. Mol. Toxicol. 21, 299-311.

Mouritsen, A., Aksglaede, L., Sørensen, K., Mogensen, S. S., Leffers, H. Main, K. M., Frederiksen, H., Andersson, A. M., Skakkebaek, N. E. and Juul, A. (2010). Hypothesis: exposure to endocrine-disrupting chemicals may interfere with timing of puberty. Int. J. Androl. 33, 346-359.

Murray, B. W., Busby, E. R., Mommsen, T. P., and Wright, P. A. (2003)
Evolution of glutamine synthetase in vertebrates: multiple glutamine synthetase genes expressed in rainbow trout (Oncorhynchus mykiss). J. Exp. Biol. 206, 1511-1521.

Ottinger, M. A., Lavoie, E., Thompson, N., Barton, A., Whitehouse, K., Barton, M., Abdelnabi, M., Quinn, M. Jr., Panzica, G., and VigliettiPanzica, C. (2008). Neuroendocrine and behavioral effects of embryonic exposure to endocrine disrupting chemicals in birds. Brain Res. Rev. 57, 376-385.

Reynaert, H., Rombouts, K., Jia, Y., Urbain, D., Chatterjee, N., Uyama, N., and Geerts, A. (2005). Somatostatin at nanomolar concentration reduces collagen I and III synthesis by, but not proliferation of activated rat hepatic stellate cells. $B r$. J. Pharmacol. 146, 77-88.

Servos, M. R., Bennie, D. T., Burnison, B. K., Jurkovic, A., McInnis, R., Neheli, T., Schnell, A., Seto, P., Smyth, S. A., and Ternes, T. A. (2005). Distribution of estrogens, 17betaestradiol and estrone, in Canadian municipal wastewater treatment plants. Sci. Total Environ. 336, 155-170.

Tusher, V. G., Tibshirani, R., and Chu, G. (2001). Significance analysis of microarrays applied to the ionizing radiation response. Proc. Natl. Acad. Sci. U.S.A. 98, 5116-5121.

United States Environmental Protection Agency. (1993). Guidelines Establishing Test Procedures for the Analysis of Pollutants, Washington, DC: U.S. Code of Federal Regulations. Title 40, Part 136, Appendix B.

Very, N. M., Kittilson, J. D., Klein, S. E., and Sheridan, M. A. (2008). Somatostatin inhibits basal and growth hormone-stimulated hepatic insulin-like growth factor-I production. Mol. Cell. Endocrinol. 281, 19-26.

Williams, D. R., Li, W., Hughes, M. A., Gonzalez, S. F., Vernon, C., Vidal, M. C., Jeney, Z., Jeney, G., Dixon, P., McAndrew, B., Bartfai, R., Orban, L., Trudeau, V., Rogers, J., Matthews, L., Fraser, E. J., Gracey, A. Y., and Cossins, A. R. (2008). Genomic resources and microarrays for the common carp (Cyprinus carpio L.). J. Fish Biol. 72, 1-32.

Williams, R. J., Johnson, A. C, Smith, J. J., and Kanda, R. (2003). Steroid estrogens profiles along river stretches arising from sewage treatment works discharges. Environ. Sci. Technol. 37, 1744-1750.

Ying, G. G., and Kookana, R. S. (2005). Sorption and degradation of estrogen-like-endocrine disrupting chemicals in soil. Environ. Toxicol. Chem. 24, 2640-2645. 
Yoon, C. G., Chung, K. W., Ham, J. H., and Jeon, J. H. (2004). Feasibility study of UV disinfection for agricultural reuse of secondary level effluent in Korea. J. Environ. Sci. Health A Tox. Hazard. Subst. Environ. Eng. 39, 835-838.

Conflict of Interest Statement: The authors declare that the research was conducted in the absence of any commercial or financial relationships that could be construed as a potential conflict of interest.

Received: 01 September 2011; accepted: 11 November 2011; published online: 02 December 2011.

Citation: Trudeau VL, Heyne B, Blais JM, Temussi F, Atkinson SK, Pakdel
F, Popesku JT, Marlatt VL, Scaiano JC, Previtera L and Lean DRS (2011) Lumiestrone is photochemically derived from estrone and may be released to the environment without detection. Front. Endocrin. 2:83. doi: 10.3389/fendo.2011.00083

This article was submitted to Frontiers in Experimental Endocrinology, a specialty of Frontiers in Endocrinology.
Copyright $(2011$ Trudeau, Heyne, Blais, Temussi, Atkinson, Pakdel, Popesku, Marlatt, Scaiano, Previtera and Lean. This is an open-access article distributed under the terms of the Creative Commons Attribution Non Commercial License, which permits non-commercial use, distribution, and reproduction in other forums, provided the original authors and source are credited. 


\section{APPENDIX}

Materials and Methods and Results for the quenching of the transient bi-radical by nitric oxide are presented in Figure A1. Formation of lumiestrone under several conditions is shown in Figures A2-A4. The effects of E1, E2 and lumiestrone on hepatic estrogen receptor expression are shown in Figure A5. The candidate genes identified using cDNA microarrays as being differentially regulated by lumiestrone are presented in Table A1.

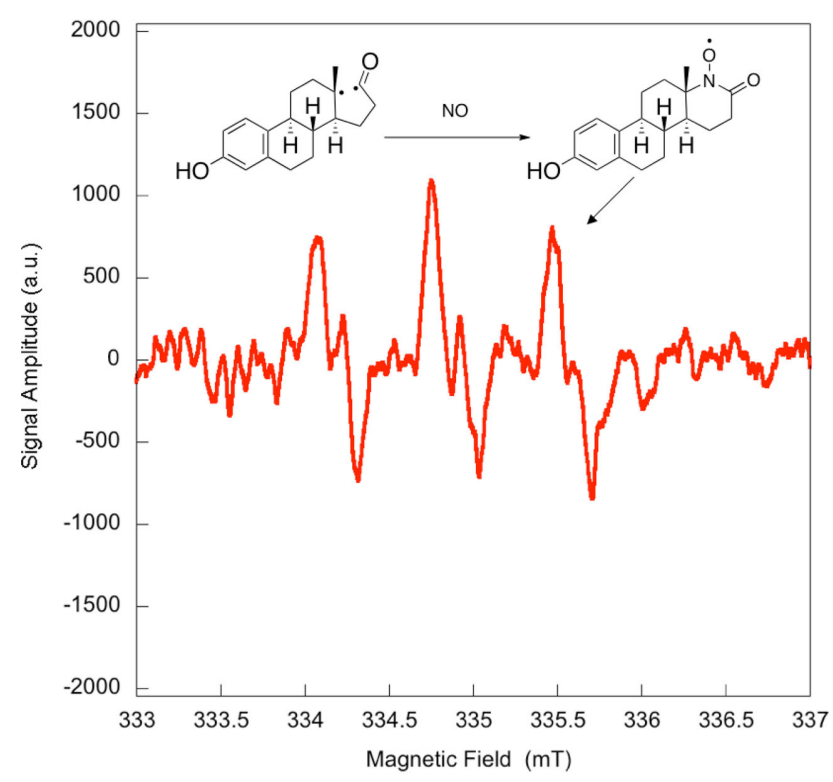

FIGURE A1 | Quenching of the transient bi-radical by nitric oxide. Electron paramagnetic resonance spectrum obtained upon irradiation of a $5 \times 10^{-4}-\mathrm{M}$ solution of estrone in acetonitrile under UV-B. A solution of estrone $(0.5 \mathrm{mM})$ dissolved in acetonitrile was degassed with nitrogen in order to avoid in situ formation of nitric dioxide. The solution was then saturated with a mixture containing $5 \%$ nitric oxide in nitrogen, and was allowed to flow through a conventional Electron paramagnetic resonance spectroscopy (EPR) flat cell (Suprasil) at a rate of $1 \mathrm{~mL} / \mathrm{min}$. The solution saturated with nitric oxide was continuously irradiated in the EPR cavity by the means of a Xenon illuminator (model LUZ-XE, Luzchem). The EPR spectra were recorded at room temperature on a FA-100 JEOL EPR spectrometer. The experimental setting was as followed: microwave power $1 \mathrm{~mW}$, modulation width $0.1 \mathrm{mT}$, sweep time $1 \mathrm{~min}$, time constant $0.03 \mathrm{~s}$ 

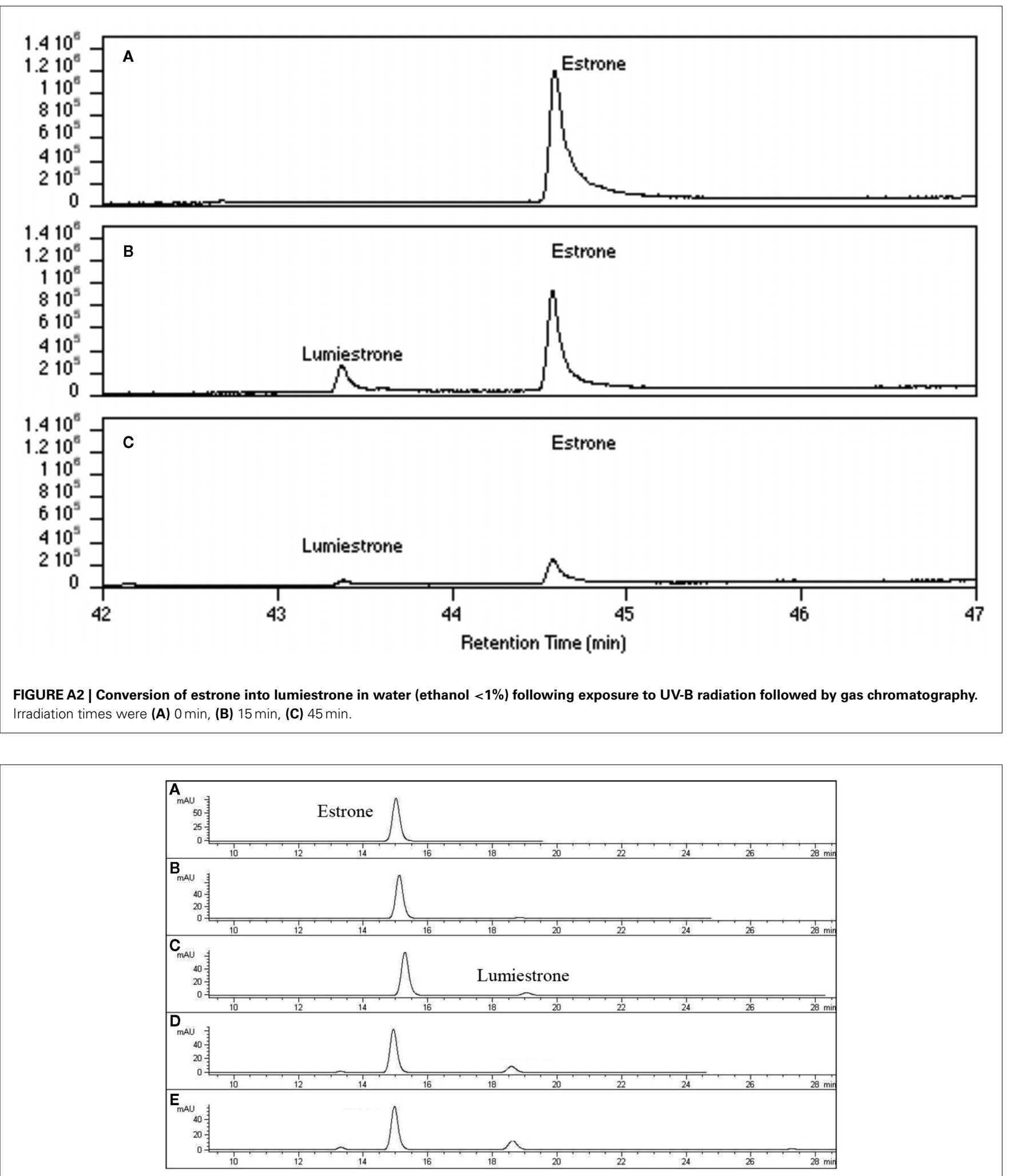

FIGURE A3 | High-pressure liquid chromatography chromatograms of estrone solutions $(10 \mu \mathrm{M})$ irradiated by sunlight at different times. (A) $t=0$, (B) $t=15$, (C) $t=60$, (D) $t=120$, and (E) $t=180 \mathrm{~min}$. In order to simulate environmental conditions estrone was dissolved in untreated sewage water and irradiated by sunlight in Napoli (Italy) in July 2007. HPLC analysis was performed under isocratic conditions $\left(\mathrm{H}_{2} \mathrm{O} / \mathrm{CH} \mathrm{H}_{3} \mathrm{CN} 1: 1\right)$ on an Agilent 1100 Binary HPLC pumps system equipped with a UV-detector. The column used was a reverse-phase Gemini $5 \mu$ C-18 $(250 \times 4.60 \mathrm{~mm})$. The detector was set at $220 \mathrm{~nm}$. 


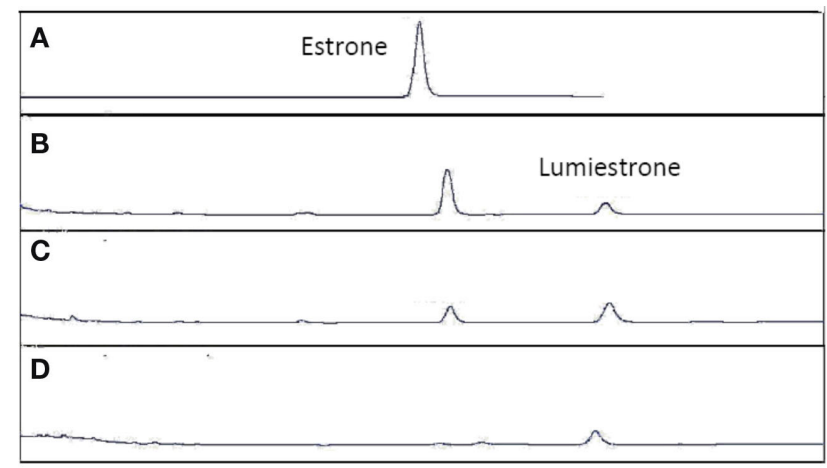

FIGURE A4 | High-pressure liquid chromatography chromatograms of estrone solutions $(10 \mu \mathrm{M})$ in untreated sewage water) irradiated by UV-B (135 $\mu \mathbf{W ~ c m}^{-2}$; Helios Italquarz) for different times. (A) $t=0$, (B) $t=1 \mathrm{~min}$, (C) $t=4 \mathrm{~min}$, and (D) $t=10 \mathrm{~min}$. HPLC analysis under isocratic conditions $\left(\mathrm{H}_{2} \mathrm{O} / \mathrm{CH}_{3} \mathrm{CN} 1: 1\right)$ was performed on an Agilent 1100 Binary HPLC pumps system equipped with a UV-detector. The column used was a reverse-phase Gemini $5 \mu$ C-18 $(250 \times 4.60 \mathrm{~mm})$. The detector was set at $220 \mathrm{~nm}$.

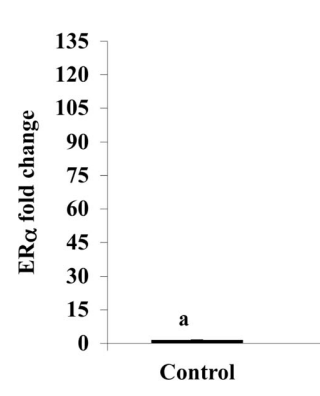

FIGURE A5 |The effect of i.p. injections $(0.5 \mu \mathrm{g} / \mathrm{g})$ of estradiol (E2), estrone (E1), lumiestrone (LE), and control (charcoal-stripped peanut oil; $5 \mu \mathrm{L} / \mathrm{g}$ ) on expression of liver estrogen receptor (ER) $\alpha$ in sexually in sexually inactive male goldfish using multiplex real-time PCR (8) after $\mathbf{2 4} \mathbf{h}$. Data $(n=6)$ are expressed as the mean $(n=6 ; \pm$ SEM) fold change relative to the $E R \beta / \beta$-actin ratios of the controls. Data were tested for normality and homoscedasity, and were transformed when appropriate prior to analysis by one-way ANOVA (treatment; $p<0.001$ ) followed by Tukey's post hoc test (S-Plus, v8.0). a,b Means labeled with different superscripts are significantly different $(p<0.05)$. Note that ER $\beta 1$ and ER $\beta 2$ mRNAs were also measured in this PCR (not shown) but were not

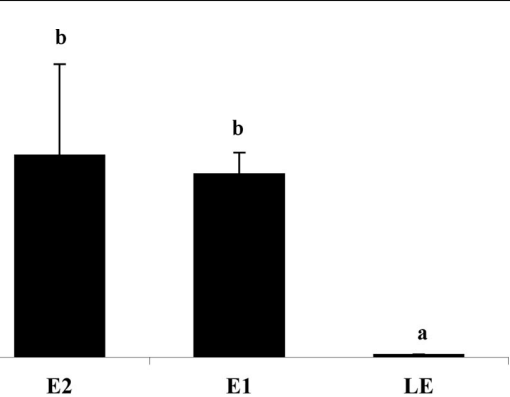

affected by treatment $(p>0.05)$. A subset $(n=3)$ of samples was screened by SYBR-Green-based PCR for vitellogenin-1 (VTG-1). VTGs are abundant phosphoproteins normally produced in the female liver that are released into circulation and accumulate in developing oocytes to provide nourishment for developing fish larvae. The gene is largely silent and undetectable in males unless they are exposed to estrogenic chemicals. No VTG-1 transcripts were amplified from control or LE-treated samples whereas it was detectable in all three of the samples from the E2 and E1-treatment groups. These data followed the general pattern for $E R \alpha$ and the average VTG-1/ $\beta$-actin ratios for control, E2, E1, and LE were respectively 0 (not-detectable), 4.2, 5.9, and 0 (not-detectable). 
Table A1 | Multilevel gene ontology classifications of transcripts expressed in male goldfish liver identified by version 1.1 of the goldfish-carp cDNA microarray to be affected by lumiestrone.

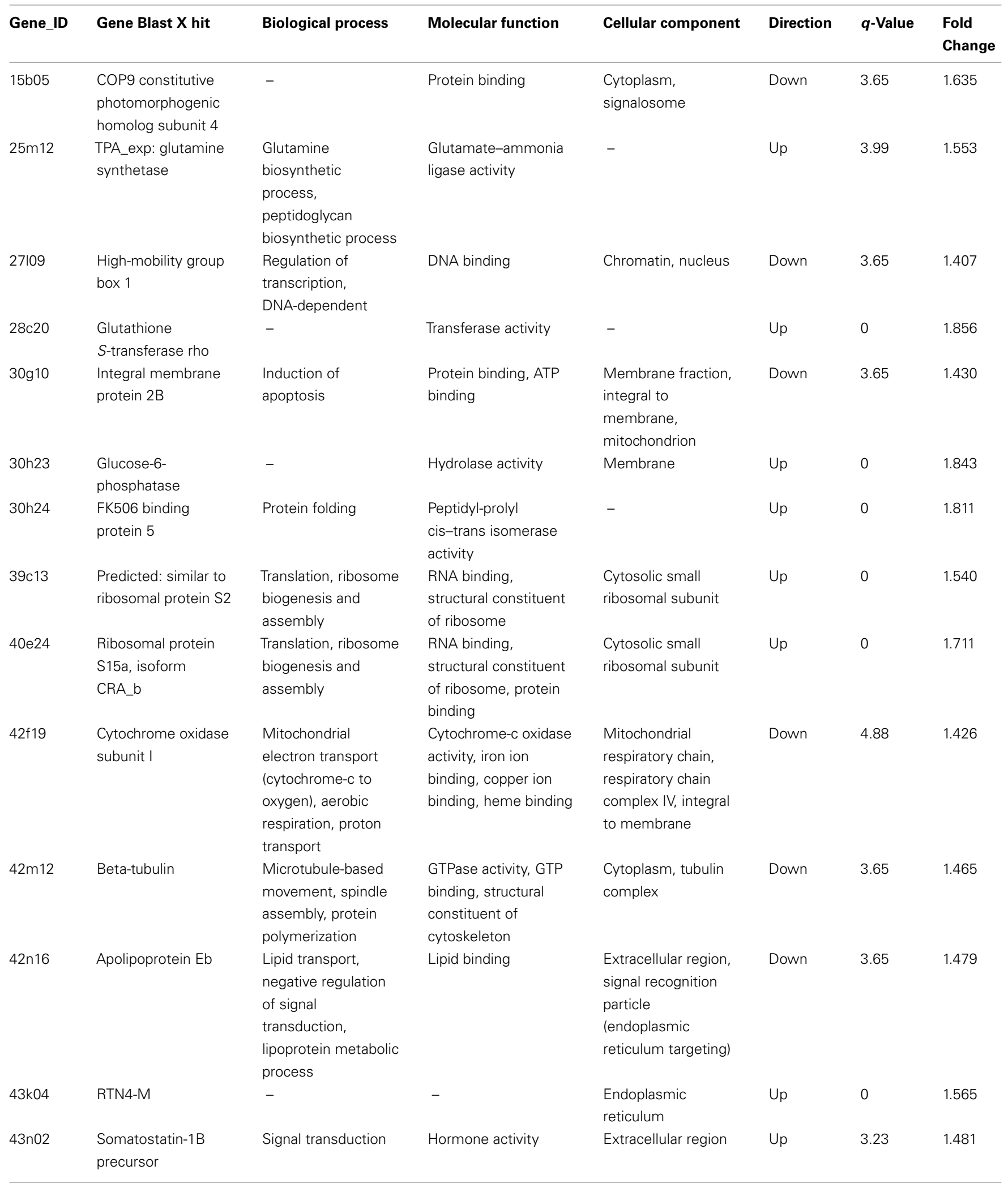


Table A1 | Continued

\begin{tabular}{|c|c|c|c|c|c|c|c|}
\hline Gene_ID & Gene Blast X hit & Biological process & Molecular function & Cellular component & Direction & $q$-Value & $\begin{array}{l}\text { Fold } \\
\text { Change }\end{array}$ \\
\hline $43 p 01$ & $\begin{array}{l}\text { Somatostatin } \\
\text { receptor type } 2\end{array}$ & $\begin{array}{l}\text { Neuropeptide } \\
\text { signaling pathway, } \\
\text { synaptic } \\
\text { transmission, } \\
\text { G-protein signaling } \\
\text { (adenylate cyclase } \\
\text { inhibiting pathway), } \\
\text { response to nutrient, } \\
\text { digestion, peristalsis, } \\
\text { negative regulation } \\
\text { of cell proliferation, } \\
\text { regulation of muscle } \\
\text { contraction }\end{array}$ & $\begin{array}{l}\text { Somatostatin receptor } \\
\text { activity, PDZ domain } \\
\text { binding, } \\
\text { melanin-concentrating } \\
\text { hormone activity, } \\
\text { purinergic nucleotide } \\
\text { receptor activity } \\
\text { (G-protein coupled), } \\
\text { neuropeptideY } \\
\text { receptor activity }\end{array}$ & $\begin{array}{l}\text { Membrane fraction, } \\
\text { integral to plasma } \\
\text { membrane }\end{array}$ & Up & 0 & 1.575 \\
\hline $55 k 21$ & $\begin{array}{l}\text { Hypothetical protein } \\
\text { LOC564707 }\end{array}$ & $\begin{array}{l}\text { Transcription } \\
\text { initiation from RNA } \\
\text { polymerase II } \\
\text { promoter, androgen } \\
\text { receptor signaling } \\
\text { pathway, positive } \\
\text { regulation of } \\
\text { transcription from } \\
\text { RNA polymerase II } \\
\text { promoter }\end{array}$ & $\begin{array}{l}\text { Thyroid hormone } \\
\text { receptor binding, } \\
\text { receptor activity, RNA } \\
\text { polymerase II } \\
\text { transcription mediator } \\
\text { activity, } \\
\text { ligand-dependent } \\
\text { nuclear receptor } \\
\text { transcription } \\
\text { coactivator activity, } \\
\text { vitamin D receptor } \\
\text { binding }\end{array}$ & $\begin{array}{l}\text { Mediator complex, } \\
\text { transcription factor } \\
\text { complex }\end{array}$ & Down & 3.65 & 1.513 \\
\hline $59 d 24$ & Transposase & $\begin{array}{l}\text { Transposition, } \\
\text { DNA-mediated }\end{array}$ & $\begin{array}{l}\text { DNA binding, } \\
\text { transposase activity }\end{array}$ & - & Down & 0 & 1.547 \\
\hline $59 k 22$ & $\begin{array}{l}\text { RNA binding motif } \\
\text { protein, } \mathrm{X} \text {-linked }\end{array}$ & - & $\begin{array}{l}\text { Nucleotide binding, } \\
\text { nucleic acid binding }\end{array}$ & $\begin{array}{l}\text { Ribonucleoprotein } \\
\text { complex }\end{array}$ & Down & 3.65 & 1.420 \\
\hline $61 \mathrm{~g} 21$ & $\begin{array}{l}\text { Hypothetical protein } \\
\text { LOC563359 }\end{array}$ & $\begin{array}{l}\text { Protein complex } \\
\text { assembly, } \\
\text { intracellular protein } \\
\text { transport, signal } \\
\text { transduction, } \\
\text { vesicle-mediated } \\
\text { transport, antigen } \\
\text { processing, and } \\
\text { presentation } \\
\text { (exogenous lipid } \\
\text { antigen via MHC } \\
\text { class Ib), positive } \\
\text { regulation of NKT } \\
\text { cell differentiation }\end{array}$ & $\begin{array}{l}\text { Receptor activity, } \\
\text { protein binding, } \\
\text { protein transporter } \\
\text { activity }\end{array}$ & $\begin{array}{l}\text { Golgi apparatus, } \\
\text { integral to } \\
\text { membrane, } \\
\text { membrane coat }\end{array}$ & Down & 4.88 & 1.399 \\
\hline
\end{tabular}

The microarray data have been submitted to GEO (GSE11252). 